\title{
Leaf Surface Characters Applied to Lauraceae Taxonomy in a Seasonal Forest of Southern Brazil
}

\author{
Guilherme Bordignon Ceolin $^{1 *}$, Jumaida Maria Rosito ${ }^{2}$ and Thais Scotti do Canto-Dorow ${ }^{2}$ \\ ${ }^{1}$ Instituto de Biociências; Universidade Federal do Rio Grande do Sul; Av. Bento Gonçalves, 950; 91501-970; \\ Porto Alegre - RS - Brasil. ${ }^{2}$ Departamento de Biologia; Universidade Federal de Santa Maria; Av. Roraima, 1000; \\ 97105-900, Santa Maria - RS - Brasil
}

\begin{abstract}
The goal of this work was to test if the macro and micro morphological analysis of the leaf surface could provide vegetative diagnostic characters for some of the most common Lauraceae species in Southern Brazilian Seasonal Forests. The leaf printing technique with universal instantaneous adhesive was used for the epidermical microscopical analysis and external macroscospical analyses of leave were made. Microscopic evaluation revealed the visibility and contours of anticlinal walls of epidermical cell and stomata and shape of guard-cells. Macroscopic evaluation showed the absence or presence of characters such as hairiness, domatia and scents. The results showed that analyzed characters, together with other diagnostic characteristics, could contribute in taxonomic delimitation of some common Lauraceae species in the Southern Brazil.
\end{abstract}

Key words: Lauraceae, leaf surface, printing, Seasonal Forests, stomata

\section{INTRODUCTION}

Seasonal forests are disjoint in South America and they are found mainly in the central, northeast and southern Brazil, in the northwest Argentina (Misiones) and southwest Bolivia. Prado and Gibbs (1993) termed them as a residual formation of dry Pleistocenic climate. In southern Brazil, especially in the southermost state of Rio Grande do Sul, the Seasonal Forests appear in northwest (Alto Uruguai) and central regions (southern hillsides of the Serra Geral range and Depressão Central) (Teixeira et al., 1986). In the Depressão Central or Jacuí River Basin, the forests are situated in the hillsides of the Serra Geral range and in softly ondulates lowlands along riparian corridors (Reitz et al., 1983). The forest is physiognomically characterized for the presence of deciduous trees in the winter, such as Apuleia leiocarpa (Vogel) Macbride, Parapiptadenia rigida (Benth.) Brenan, Peltophorum dubium (Spreng.) Taub. and Cabralea canjerana (Vell.) Mart. Amongst the perennial trees, species of Lauraceae family are important, such as Aiouea saligna, Ocotea spp. and Nectandra spp. (Quadros and Pillar, 2002), and are widely used since $19^{\text {th }}$ century for naval construction and timbers (Cante, 1988). Moreover, it presents great ecological importance due to its wide distribution and high richness in floristic and structural surveys (Backes and Irgang, 2002). The family has pan-tropical distribution and has 19 genera and 390 species in Brazil (Barroso et al., 2002). In Rio Grande do Sul State, there are 30 species (Backes and Nardino,

*Author for correspondence: guibceolin@ hotmail.com 
1998), with close vegetative similarity among them that poses difficulty to recognize and distinct different taxa. Leaf anatomy, especially epidermical analyses is an efficient tool in taxonomic determination, supplying excellent descriptors. Characters such as trichomes and stomata are useful, as they are highly meaningful in vascular plant taxonomy (Metcalfe and Chalk, 1979; Yang and Lin, 2005; Milan et al., 2006). Morfoanatomical leaves descriptions have been carried out in many species as taxonomic subsidy in non-fertile samples (Paoli and Mina-Rodrigues, 1992). Duke (1969), when studying the development of seedlings, pointed out that leaf morphology had great importance on species identification. Despite wide use, anatomical studies apply laborious techniques (Macedo, 1997) that make work hard and long time-consuming. Segatto et al. (2004) demonstrated a study of leaf epidermis anatomy in potato clones (Solanum tuberosum L.) by an alternative technique, the printing out of leaf epidermis with cianoacrilate ester universal instantaneous adhesive.

The aim of this work was to identify some Lauraceae tree species from remnants of Seasonal Forests at Serra Geral formation, Rio Grande do Sul state, applying the epidermical printing technique with cianocrilate ester as an alternative anatomic tool.

\section{MATERIAL AND METHODS}

\section{Sample area}

The present study was carried out in the municipality of Santa Maria in Rio Grande do Sul state, Southern Brazil, between the Depressão Central and the Serra Geral range, around the coordinates $29^{\circ} 41^{\prime} 25^{\prime \prime} \mathrm{S}$ and $53^{\circ} 48^{\prime} 42^{\prime \prime} \mathrm{W}$. According to Köppen classification, the climate of region is Cfa (Moreno, 1961), presenting welldistributed rains along the year and average annual temperature higher than $18^{\circ} \mathrm{C}$ (Budke et al., 2004). The sample area enclosed some points pertaining to natural native forests or little modified from Seasonal Forests of the hillside of the Serra Geral range, called local as "Morro do Elefante", "Morro do Cerrito" and "Morro da Boca do Monte", beyond small fragments or isolated individuals, located at the diverse points of the municipality.

\section{Tree species}

Through the checklists (Machado and Longhi, 1990; Longhi et al., 2000), the following species were selected for the study: Aiouea saligna Meis., Nectandra lanceolata Nees, Nectandra megapotamica (Spreng.) Mez, Ocotea puberula (Rich.) Nees and Ocotea pulchella (Nees) Mez. Two or three plants of each species were surveyed at different points described above. Fertile branches were collected to confirm the species identification and voucher materials were incorporated to SMDB herbarium with the following numbers: SMDB 9488, SMDB 9496, SMDB 9498, SMDB 9646, SMDB 9647, SMDB 9648 and SMDB 9692.

\section{Slides and describers}

For slides, adult leaves completely expanded from different heights in the same tree were used, in order to encompass the whole solar exposure to verify if different solar exposure would make any difference in the epidermical structures. For the micromorphological analysis, the technique described by Segatto et al. (2004) was applied where the medium leaf part was separated with a razor blade and then it was used for the printing of abaxial and adaxial faces. After that a drop of cianoacrilate ester was added in a histological slide and pressured the set for approximately thirty seconds and then the apparatus was removed, leaving in the slide the impression of each leaf epidermis. Slides were analyzed in an optic Olympus microscope at 100 and $400 \mathrm{x}$ and photographed with a connected camera. The photographs were analyzed in order to describe the epidermical patterns. Macro morphological analysis was obtained using a stereomicroscope until $4 \mathrm{x}$. The terms describing the characters followed Hickey (1973) and Radford et al. (1974).

\section{RESULTS}

Macroscopically, the analyzed species presented differences regarding domatia, trichomes and the presence or absence of scent. Microscopically, they could be differentiated regarding the visibility and contours of anticlinal walls of epidermical cells, as well as the visibility of stomata and shape of guard-cells. The micro morphological analysis showed that all the Lauraceae species presented 
hypostomatic leaves, with paracitic type stomata. The macro morphological analyses demonstrated a pattern of simple entire leaves, glabrous or piloses, some with domatia; others presenting characteristic scent when smashed due to the presence of oleiferous cells in mesophyll. Structural differences in epidermis had not been found in leaves at different heights of trees in the studied species.The characteristics that allowed differentiating the taxa are described below and summarized in Table 1 (the characters are only valid using printing technique):

Aiouea saligna (Figs. 1 a, b) Macro: glabrous leaves; domatia absent; without characteristic scent. Micro: epidermical cells with no-definite contour. When apparent, the anticlinal walls revealed very sinuous in both faces; stomata visible in $100 \mathrm{x}$; guard-cells with elliptical shape.

Nectandra megapotamica (Figs. 1 c, d) - Macro: glabrous leaves; domatia absent; with characteristic scent. Micro: epidermical cells with straight walls in both faces; stomata printing almost imperceptible $(100 \mathrm{x})$; guard-cells very small.

Nectandra lanceolata (Figs. 1 e, f) Macro: densely pilous leaves in the abaxial face with yellow trichomes; domatia presence in some individuals; with characteristic scent. Micro: epidermical cells with straight walls in both faces; stomata clearly visible $(100 \mathrm{x})$; guard-cells with squared shape.

Ocotea puberula (Figs. 1 g, h) - Macro: glabrous leaves or rare piloses; domatia absent; without or rare characteristic scent. Micro: epidermical cells with sinuous walls in abaxial face. In adaxial face, cell walls seems straight; stomata clearly visible $(100 \mathrm{x})$; guard-cells with elliptical shape.

Ocotea pulchella (Figs. 1 i) - Macro: spread pilous leaves in both faces; domatia presence; with characteristic scent. Micro: epidermical cells with sinuous walls in abaxial face. In adaxial face, cell walls seems straight; stomata clearly visible (100 $\mathrm{x})$; guard-cells with elliptical shape.

Table 1 - Leaf surface characters used for taxonomic differentiation in Lauraceae species. The signs + and indicates presence or absence of characters respectively. The sign $+/$ - indicates intermediate pattern. Abbreviations: abf $=$ abaxial face; adf $=$ adaxial face; $b f=$ both faces; $w a=$ when apparent.

\begin{tabular}{|c|c|c|c|c|c|c|c|}
\hline & \multicolumn{3}{|c|}{ Macro-characters } & \multicolumn{4}{|c|}{ Micro-characters } \\
\hline & Hairiness & Domatia & Scent & $\begin{array}{c}\text { Guard-cells } \\
\text { shape }\end{array}$ & $\begin{array}{l}\text { Stomata } \\
\text { visibility }\end{array}$ & $\begin{array}{c}\text { Epidermic } \\
\text { cell anticlinal } \\
\text { walls contour }\end{array}$ & $\begin{array}{l}\text { Epidermic cell } \\
\text { anticlinal } \\
\text { walls visibility }\end{array}$ \\
\hline $\begin{array}{l}\text { Aiouea } \\
\text { saligna }\end{array}$ & - & - & - & Elliptical & + & $\begin{array}{l}\text { Sinuous } \\
\text { (bf/wa) }\end{array}$ & $+/-$ \\
\hline $\begin{array}{l}\text { Nectandra } \\
\text { megapotamica }\end{array}$ & - & - & + & No apparent & - & Straight(bf) & + \\
\hline $\begin{array}{l}\text { Nectandra } \\
\text { lanceolata }\end{array}$ & $+(a b f)$ & $+/-$ & + & Square & + & Straight(bf) & + \\
\hline $\begin{array}{l}\text { Ocotea } \\
\text { puberula }\end{array}$ & $+/-(\mathrm{abf})$ & - & $+/-$ & Elliptical & + & $\begin{array}{l}\text { Sinuous(abf) } \\
\text { and } \\
\text { straight(adf) }\end{array}$ & + \\
\hline $\begin{array}{l}\text { Ocotea } \\
\text { pulchella }\end{array}$ & $+(\mathrm{bf})$ & + & + & Elliptical & + & $\begin{array}{c}\text { Sinuous(abf) } \\
\text { and } \\
\text { straight(adf) }\end{array}$ & + \\
\hline
\end{tabular}



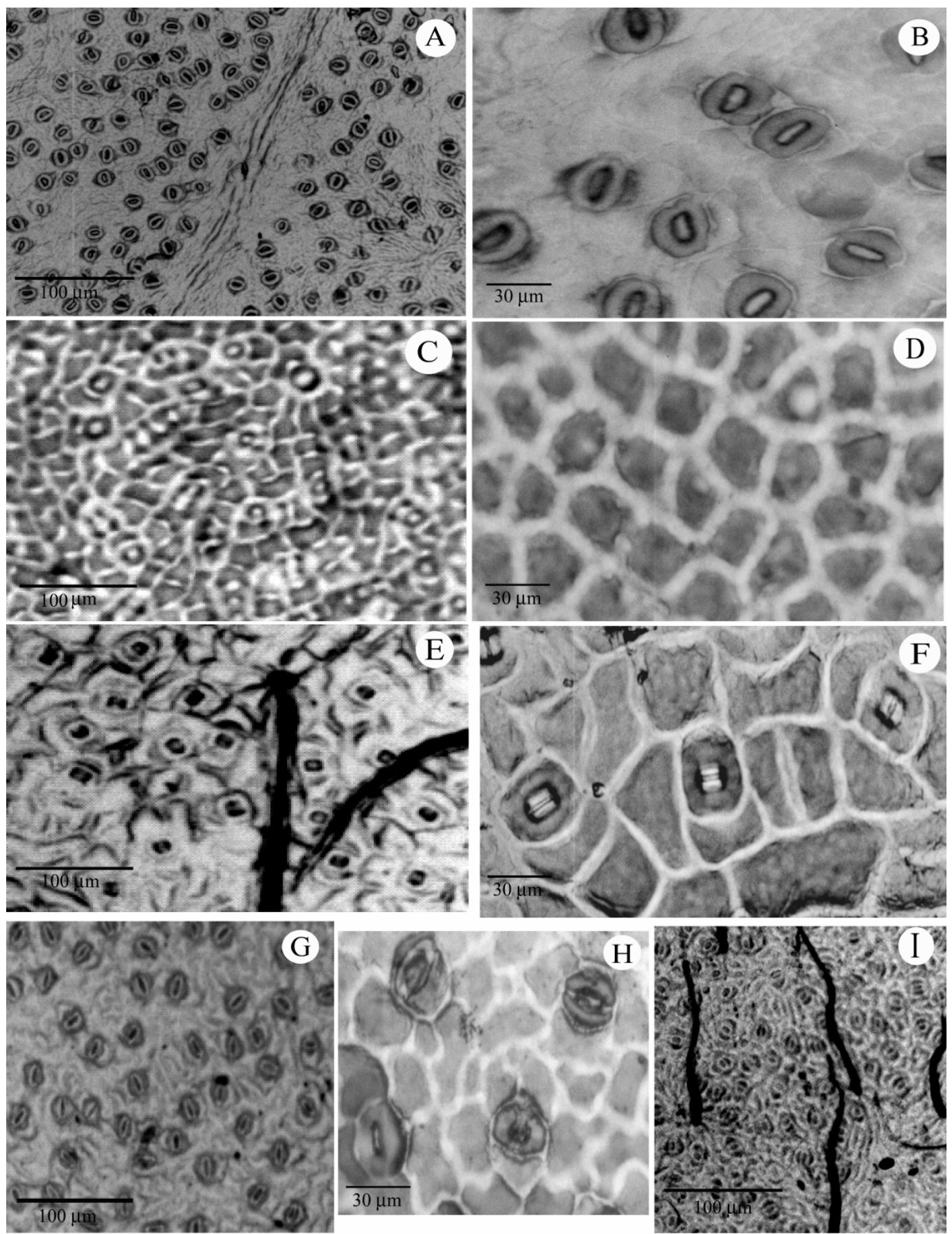

Figure 1 - Leaf surface characters: Aiouea saligna - A) Stomata visibility (100x); B) Cells with no apparent contour. Nectandra megapotamica - C) Stomata no visibility (100x); D) Adaxial face cells with straight anticlinal walls contour. Nectandra lanceolata - E) Stomata visibility and trichomes (100x); F) Stomata shape and cells with straight anticlinal walls contour. Ocotea puberula - G) Stomata visibility (100x); H) Stomata shape and cells with sinuous anticlinal walls contour. Ocotea pulchella - I) Stomata visibility and trichomes (100x). 


\section{DISCUSSION}

Genera circumscription in Lauraceae family has been interpreted in different ways (Nees, 1833; Meisner, 1864; Mez, 1889). The importance attributed to floral characters in detriment of vegetative characters frequently is credited as inadequate due to overlapping of same ones in intermediate specimens. Therefore, it is necessary to study different attributes associated to them, such as roots and wood anatomy (Richter, 1980) and leaf venation (Nishida, 1999) that increase taxa delimitation at different levels. Some studies (Fagetter, 1987; Moraes and Paoli, 1999) reported that micromorphology of leaf epidermis supplies some characters of diagnostic value in Lauraceae taxonomy. However, present results demonstrated that the combination of a macro and micro morphological simple analysis of leaf could be helpful (together other characters) in taxonomic identification of some species in the family. Pedralli (1987), for example, considered the ratio between the inflorescence length in relation to leaf size and the ratio of berry inclusion in the couple to delimit Nectandra species in Santa Catarina state. Vattimo $(1956,1979)$ gave great importance for fruit morphology in delimitation of some genera. On the other hand, Werff (1991) found that the majority of identification keys and Lauraceae taxonomic studies were based on floral characters. These characters present some limitations, because the measures and ratios vary between the individuals. Some environmental factors, such as solar radiation may affect the leaf size (Cutter, 1986) and the presence of flowers and/or fruits could be a consequence of phenological phases and might not be available at the time of sampling. Werf and Richter (1996) reported that floral characters were frequently changeable within the genera. Such characters exclusively may be not sufficient to identify the plants until species, allowing the identification until genus or merely the family (Pereira-Silva et al., 2004), not only in Lauraceae but also in other botanical families, with equal or higher taxonomic difficulty.

Leaf (especially epidermis) is an organ that suffers the highest variation due to environmental conditions (Cutter, 1986). Pyykkö (1979) suggested that there could be a correlation between the epidermic cells wall sinuosity and luminous intensity: straight lines to strong sinuous in upper and lower forest strata, respectively. Cutler (1972) and Cutler and Brandham (1977), studying the Liliaceae family, demonstrated that epidermic cell patterns and stomata structural details, when seen from the foliar surface, seemed to be under strong genetic control in Aloineae tribe members. Cutler (1969) also reported that, if epidermical patterns presented enough steady and differed from species to species, they could provide additional taxonomic characters to help the identification of non-fertile plants. In the present study, the wall sinuosity variation was more related to genus than the environmental conditions, since the format of structures showed no significant variations, although were collected at different plant height strata. These results were in agreement with Moraes and Paoli (1999) where individuals of Endlicheria paniculata (Spreng.) $\mathrm{McBr}$. showed straight lines cell walls in full sun as well as in sub-forest. Moreover, in this same study, individuals of Ocotea catharinensis Mez and Cryptocarya moschata Nees showed cell walls from little to strongly sinuous in individuals belonging to upper strata of forest, opposing to Pyykkö's (1979) correlation. Furthermore, Toledo et al. (2004) found no differences in leaf structure when studied individuals of Ocotea odorifera (Vell.) Rohwer growing on two environments, confirming the apparent genetic control of cell shape indicated by Cutler (1972).

In summary, both the analysis (micro and macro) confirmed the family standard as found by other authors (Christophel et al., 1996; Marchiori, 1997; Marques, 2001; Boeger et al., 2004).

According to Petzold (1907), the presence of epidermical cells with straight lines (predominant in the family) or sinuous anticlinal walls is an important character in differentiation of Lauraceae species. The genera Aniba, Aiouea and Cryptocarya hold many species with sinuous cells as a pattern (Moraes and Paoli, 1999). In the present study, cells with straight lines anticlinal walls appeared in both faces of Nectandra species analyzed. The sinuous anticlinal walls appeared in Aiouea in both faces. Ocotea presented sinuous wall cells in the abaxial face, being the adaxial face wall cells straight lines, in agreement with Farago et al. (2005).

Many dicotyledoneous species (s.l.) show some domatia types in the abaxial face with important taxonomic value, since they present a configuration more or less uniform for determined taxonomic category (Adâmoli de Barros, 1961). Santos and Oliveira (1990), studying domatia 
found in three Ocotea species, found that in $O$. pulchella, the domatia were present in basal and medium third of the leaf blade. However, when in high number, they could reach until apex, not necessarily appearing in the first armpit, being able to be present in second, third and even fourth armpit. In the present study, domatia were found in abaxial face of the ample majority of $O$. pulchella leaves but not in $O$. puberula, as described by Reitz et al. (1983) and Marchiori (1997). This could be considered as a suitable character to be used as a marker to differentiate two Ocotea species. In Nectandra lanceolata, domatia were occasionally found; however, the distinguishing presence of abundant yellow trichomes, distributed in all leaf blade, as well as own characteristics of species, such as squaredshape guard-cell allowed the safe differentiation between the two species. Scents and tastes are subjective characters, but must not be neglected because they could play an important role such as auxiliary character to identify the families or species that possess them as a strong marker, as Lauraceae, Myrtaceae and Rutaceae (Sobral et al., 2006).

In relation to technique used in the present study, Segatto et al. (2004) proved that epidermical printing with cianoacrilate ester universal instantaneous adhesive was a valid technique in leaf surface anatomical studies, therefore allowed the visualization of epidermical cells, stomata and trichomes, showing shape, contour, arrangement and distribution on leaf surface. The authors also demonstrated the protocols as a fast technique, of easy execution and providing permanent material. All these advantages contribute to make this technique a useful tool in anatomical works with taxonomic scope, decreasing costs, and reducing the slide confection time.

This work demonstrated that a combination of macro and micro epidermical leaf analysis, together with other diagnostic characteristic can be useful like a taxonomic subsidy in identification of Lauraceae species in vegetative conditions, opening the way for its use in other botanical families, mainly to facilitate the seedlings identification in natural regeneration studies.

\section{ACKNOWLEDGEMENTS}

The authors would like to thank Dr. Solon Jonas Longhi for his help in plant identification, Dr. Jean Carlos Budke and Msc. Eduardo L.H. Giehl for English revision and critical suggestions and also to Carla M. G. de Pelegrin and Adriano Silvério for help with photomicroscopy.

\section{RESUMO}

Este trabalho teve por objetivo testar se a análise macro e micro morfológica da superfície foliar poderia prover caracteres diagnósticos vegetativos para algumas das espécies mais comuns de Lauraceae encontradas em Florestas Estacionais do sul do Brasil. Utilizou-se a técnica de impressão foliar com adesivo instantâneo universal para a análise microscópica da epiderme e procederam-se análises externas macroscópicas das folhas. Microscopicamente, foram utilizados a visibilidade e os contornos das paredes anticlinais das células epidérmicas, bem como a visibilidade dos estômatos e o formato de suas células-guarda. Macroscopicamente, verificaram-se a presença ou ausência de caracteres como pilosidade, domácias e odores. Os resultados obtidos no trabalho mostraram que os caracteres analisados, juntamente com outras características diagnósticas, podem contribuir na delimitação taxonômica de algumas espécies da família comuns no sul do Brasil.

\section{REFERENCES}

Adâmoli de Barros, M. A. (1961), Ocorrência das domácias nas Angiospermas. Anais da Escola Superior de Agricultura “Luiz de Queiroz” 18, 113130.

Backes, A. and Nardino, M. (1998), Árvores, arbustos e algumas lianas nativas do Rio Grande do Sul. Unisinos, São Leopoldo.

Backes, P. and Irgang, B. E. (2002), Árvores do Sul Guia de Identificação e Interesse Ecológico. Instituto Souza Cruz, Santa Cruz do Sul. 
Barroso, G. M.; Peixoto, A. L.; Ichaso, C. L. F.; Guimarães, E. F. and Costa, C. G. (2002), Sistemática das angiospermas do Brasil, vol. 1. Universidade Federal de Viçosa, Viçosa.

Boeger, M. R. T.; Alves, L. C. and Negrelle, R. R. B. (2004), Leaf morphology of 89 tree species from a Lowland Tropical Rain Forest (Atlantic Forest) in South Brazil. Brazilian Archives of Biology and Technology, 47, 933-943.

Budke, J. C.; Giehl, E. L. H.; Athayde, E. A. and Záchia, R. A. (2004), Distribuição espacial de Mesadenella cuspidata (Lindl.) Garay (Orchidaceae) em uma floresta ribeirinha em Santa Maria, RS, Brasil. Acta Botanica Brasilica, 18, 31-35.

Cante,T. (1988), O móvel do século XIX no Brasil. CGPM, Rio de Janeiro.

Christophel, D. C.; Kerrigan, R. and Rowett, A. I. (1996), The use of cuticular features in the taxonomy of the Lauraceae. Annals of the Missouri Botanical Garden, 83, 419-432.

Cutler, D. F. (1969), Cuticular markings and other epidermical features in Aloe leaves. Notes Jodre Laboratories, 4, 21-27.

Cutler, D. F. (1972), Leaf anatomy of certains Aloe and Gasteria species and their hybrids. In - Research Trends in Plant Anatomy, eds. Ghouse, A.K.M. and Yunus, M. Tata McGraw-Hill, New Delhi, pp. 103122.

Cutler, D. F. and Brandham, P. E. (1977), Experimental evidence for the genetic control of leaf surface in hybrid Aloineae (Liliaceae). Kew Bulletin, 32, 23-32.

Cutter, E. G. (1986), Anatomia Vegetal - Experimentos e Interpretações. Parte II - Órgãos. Roca, Botucatu.

Duke, J. A. (1969), On tropical tree seedlings. I. Seeds, seedlings, systems and systematics. Annals of the Missouri Botanical Garden, 56, 125-161.

Faggetter, C.D. (1987), Leaf cuticles (phytoglyphs) of selected Lauraceae. In - Anatomy of the Dicotyledons, ed Metcalfe, C.R. Claredon Press, Oxford, pp. 157160.

Farago, P. V.; Budel, J. M.; Duarte, M. R. and Nakashima, T. (2005), Análise morfoanatômica de folhas de Ocotea puberula (Rich.) Nees, Lauraceae. Revista Brasileira de Farmacognosia, 15, 250-255.

Hickey, L. J. (1973), Classification of the architecture of dicotyledoneous leaves. American Journal of Botany, 60, 1-26.

Longhi, S. J.; Araujo, M. M.; Kelling, M. B.; Hoppe, J. M.; Müller, I. and Borsoi, G. A. (2000), Aspectos fitossociológicos de fragmento de Floresta Estacional Decidual em Santa Maria, RS. Ciência Florestal, 10, 59-74.

Machado, P. F. S. and Longhi, S. J. (1990), Aspectos florísticos e fitossociológicos do Morro do Elefante em Santa Maria, RS. Revista do Centro de Ciências Rurais, 20, 261-280.
Macedo, N. A. (1997), Manual de técnicas em histologia vegetal. Universidade Estadual de Feira de Santana, Feira de Santana:

Marchiori, J. N. C. (1997), Dendrologia das Angiospermas - Das Magnoliáceas as Flacourtiáceas. Universidade Federal de Santa Maria, Santa Maria.

Marques, C. A. (2001), Anatomia foliar aplicada à taxonomia de espécies de Lauraceae Lindl. M. Sc. Thesis, Universidade Federal de Viçosa, Viçosa, Brasil.

Meisner, C. F. (1864), Lauraceae. In - Prodromus systematis naturalis regni vegetabilis, ed. Decandolle, A. pp. 1-260.

Metcalfe, C. R. and Chalk, L. (1979), Anatomy of the dicotyledons: systematic anatomy of the leaf and stem. Oxford University, New York.

Mez, C. (1889), Lauraceae Americanae. Jahrbuch des Königlichen botanischen Gartens und des botanichen Museums zu. Berlin 5, 1-556.

Milan, P.; Hayashi, A. H. and Appezzato-da-Glória, B. (2006), Comparative leaf morphology and anatomy of three Asteraceae species. Brazilian Archives of Biology and Technology, 49, 135-144.

Moraes, P. R. L. and Paoli, A. A. S. (1999). Epiderme e padrão de venação foliar de espécies de Lauraceae. Acta Botanica Brasilica, 13, 87-97.

Moreno, J. A. (1961), Clima do Rio Grande do Sul. Secretaria da Agricultura - Div. Terras e Colonização, Porto Alegre.

Nees, C. G. D. (1833), Revision laurinarum ab Sellowio in Brasilia collectarum et iam in Herbário Regio Berolinensi asservatarum. Linnaea, 8, 1-37.

Nishida, S. (1999), Revision of Beilschmiedia (Lauraceae) in the Neotropics. Annals of the Missouri Botanical Garden, 86, 657-701.

Paoli, A. A. S. and Mina-Rodrigues, E. M. C. (1992), Estudo morfoanatômico de folhas de Trichilia claussenii e Trichilia pallida (Meliaceae). Napaea, 8, 21-28.

Pedralli, G. (1987), Lauráceas - Nectandra. In - Flora Ilustrada Catarinense, ed. Reitz, R. Herbário Barbosa Rodrigues, Itajaí.

Pereira-Silva, E. F. L.; Santos, J. E.; Kageyama, P. Y. and Hardt, E. (2004), Florística e fitossociologia dos estratos arbustivo e arbóreo de um remanescente de cerradão em uma Unidade de Conservação do Estado de São Paulo. Revista Brasileira de Botânica, 27, 533-544.

Petzold, V. (1907), Systematisch-anatomische Untersuchungen über die Laublätter der amerikanischen Lauraceen. Botanische Jahrbücher für Systematik, Pflanzengeschichte und Pflanzengeographie, 38, 445-474.

Prado, D. E. and Gibbs, P. E. (1993), Patterns of species distributions in the dry seasonal forest South America. Annals of the Missouri Botanical Garden, 80, 902-927. 
Pyykkö, M. (1979), Morphology and anatomy of leaves from some woody plants in a humid tropical forest of Venezuelan Guayana. Acta Botanica Fennica, 112, 141.

Quadros, F. L. F. and Pillar, V. P. (2002), Transições Floresta-Campo no Rio Grande do Sul. Ciência e Ambiente, 24, 109-119.

Radford, A.; Dickison, W. C.; Massey, J. R. and Bell, R. C. (1974), Vascular Plant Systematics. Harper and Row, New York.

Reitz, R.; Klein, R.M. and Reis, A. (1983), Projeto Madeira do Rio Grande do Sul. Sellowia, 34-35, 1525.

Richter, H. G. (1980), Occurrence, morphology and taxonomic implications of crystalline and siliceous inclusions in the secondary xylem of the Lauraceae and related families. Wood Science and Technology, 14, 35-44.

Santos, M and Oliveira, P. L. (1990), Domácias do gênero Ocotea Aubl. (Lauraceae). Insula, 19, 16-36.

Segatto, F. B.; Bisognin, D. A.; Benedetti, M.; Costa, L. C.; Rampelotto, M. V.and Nicoloso, F. T. (2004), Técnica para estudo da anatomia da epiderme foliar de batata. Ciência Rural, 34, 1597-1601.

Sobral, M.; Jarenkow, J. A.; Brack, P.; Irgang, B. E.; Larocca, J.; Rodrigues, R.S. (2006), Flora arbórea e arborescente do Rio Grande do Sul, Brasil. Rima and Novo Ambiente, Porto Alegre.

Teixeira, M. B., Coura Neto, A. B., Pastore, U. and Rangel Filho, A. L. R. (1986), Vegetação. As regiões fitoecológicas, sua natureza e seus recursos econômicos. Estudo fitogeográfico. Rio de Janeiro, IBGE, pp. 541-632.
Toledo, M. G. T. de; Alquini, Y. and Nakashima, T. (2004), Aspectos estruturais das folhas de Ocotea odoifera (Vell.) Rohwer (Lauraceae) em dois ambientes distintos. Revista Brasileira de Farmácia, 85, 89-93.

Vattimo, I. (1956), O gênero Ocotea Aubl. no sul do Brasil - Espécies de Santa Catarina e do Paraná. Rodriguésia, 18/19, 265-349.

Vattimo, I. (1979), Lauráceas - 1. Cryptocaria, 2. Endlicheria, 3. Licaria, 4. Aiouea, 5. Aniba. In Flora Ilustrada Catarinense, ed. Reitz, R. Herbário Barbosa Rodrigues, Itajaí.

Werff, H. van der. (1991), A key to the genera of Lauraceae in the New World. Annals of the Missouri Botanical Garden, 80, 377-387.

Werff, H. Van Der and Richter, H. G. (1996), Toward an improved classification of Lauraceae. Annals of the Missouri Botanical Garden, 83, 409-418.

Yang, Z. R.; Lin, Q. (2005), Comparative morphology of the leaf epidermis in Schisandra (Schisandraceae). Botanical Journal of the Linnean Society, 148, 39-56

Received: October 31, 2006; Revised: May 07, 2007, Accepted: February 11, 2009. 